\title{
Solar Energy Potential Assessment in the Algerian South Area: Case of Ghardaiia Region
}

\author{
Kacem Gairaa and Yahia Bakelli \\ Unité de Recherche Appliquée en Energies Renouvelables, URAER, Centre de Développement des Energies Renouvelables, CDER, \\ 47133 Ghardaïa, Algeria
}

Correspondence should be addressed to Kacem Gairaa; gisol47@gmail.com

Received 5 December 2012; Revised 17 February 2013; Accepted 23 February 2013

Academic Editor: Jayanta Deb Mondol

Copyright (C) 2013 K. Gairaa and Y. Bakelli. This is an open access article distributed under the Creative Commons Attribution License, which permits unrestricted use, distribution, and reproduction in any medium, provided the original work is properly cited.

\begin{abstract}
Due to its geographical position in the solar belt, Algeria is blessed with an abundance of solar energy and has the opportunity to utilize this bounty of natural energy effectively, promoting a clean environment and developing renewable energy technologies in the region. This paper assesses and analyses the solar energy potential in Ghardaïa area (south Algeria) to help users for solar energy applications. A database of solar radiation components has been employed for this purpose. The data presented in the paper are compared with other data supplied by renowned regional and international establishments, such as the solar atlas for the Mediterranean and the NASA. The frequency and the hourly distribution of solar radiation components indicate that the region is considered as an economical area and favorable for solar applications, such as the photovoltaic and the concentrating solar power (CSP) technologies. In addition to solar radiation, data of two functions, namely, clearness index and sunshine fraction have been examined; their results specify that the site has a clear sky conditions in most time of the year. In general, the obtained results illustrate that the site under consideration can use solar energy as a promising solution to conventional energy.
\end{abstract}

\section{Introduction}

In the recent years, Algeria has approved its determination to contribute to the world efforts to combat the global warming and protect the environment. Throughout this goal, a dynamic green energy has been initiated by launching an ambitious program of development of renewable energy and energy efficiency. This vision is based on a strategy focused on the development of inexhaustible resources, such as solar energy. The program aims to achieve a renewable power installations of about 22000 (MW) between 2011 and 2030, of which 12000 (MW) will be oriented to cover the national demand and 10000 (MW) for export. So, renewable energies are placed at the center of economic and energy policy awareness of the country. About $40 \%$ of electricity production for domestic consumption will be issued from renewable sources, by the year 2030. Indeed, our country will become an important player in the production of electricity from solar photovoltaic and solar thermal [1]. Large-scale projects to exploit renewable resources, in particular, solar energy, are already underway; we can cite as example, the photovoltaic solar power plant of Oued Nechou (20 km north of Ghardaïa) with a production capacity of 1.1 (MW) to generate solar electricity, and the thermal solar plant of Hassi R'Mel $(100 \mathrm{~km}$ north of Ghardaiia) that uses CSP technology with a capacity of 150 (MW) which is operational since July 2011.

Nowadays, the world is interested by the renewable energies more than before to reduce the greenhouse effect, caused by the absurd exploitation of conventional sources. Thus, knowing the amount of solar radiation potential of a given site is required to convert sunlight rays into another form of energy.

Therefore, many studies were developed to evaluate the solar potential in many areas of the Middle East and North Africa (MENA) region. Alnaser et al. [2] have established a solar atlas of the Arab world; this atlas contains four kinds of information: the sunshine duration, diffuse solar radiation, the DNI solar radiation, and the global solar radiation. It contains data from 280 stations in 19 Arab states, sweeping latitudes $0^{\circ}$ (tropical) to $37^{\circ}$ north and longitude $19^{\circ}$ west 
to $60^{\circ}$ east. They reported that the maximum value of the average annual global solar radiation in the MENA region was $6.7\left(\mathrm{kWh} / \mathrm{m}^{2}\right)$ detected in Nouakchott (Mauritania) and $6.6\left(\mathrm{kWh} / \mathrm{m}^{2}\right)$ in Tamanrasset (Algeria). The maximum annual average sunshine duration was recorded in Aswan (Egypt) with 10.7 hours of sunshine, while the lower value is recorded in Tunis with 7.5 hours of sunshine duration.

Trabea [3] has analysed solar radiation measurements at Al-Arish site (Egypt). He presented a database for five years from 1986 to 1990 for the global and the diffuse solar radiation; his study shows that the monthly average daily values of global solar radiation reach $8000\left(\mathrm{Wh} / \mathrm{m}^{2} /\right.$ day $)$ in summer, $4322\left(\mathrm{Wh} / \mathrm{m}^{2} /\right.$ day $)$ in spring and autumn, and 2917 $\left(\mathrm{Wh} / \mathrm{m}^{2} /\right.$ day) in the winter season.

Shaltout et al. [4] have studied the solar radiation at Menia site (Egypt). They used measurements of one complete year from January 1 to December 31, 1997; they concluded that the highest values of global solar radiation on horizontal surface were in summer season with a mean value of 775 $\left(\mathrm{W} / \mathrm{m}^{2}\right)$, while the lower ones were found in winter with an average value of $487\left(\mathrm{~W} / \mathrm{m}^{2}\right)$. Regarding the direct solar radiation, the highest values were recorded in summer with a value of $778\left(\mathrm{~W} / \mathrm{m}^{2}\right)$, where the lower one was detected in autumn season with a value of $691\left(\mathrm{~W} / \mathrm{m}^{2}\right)$. Al-Mohamad [5] has established solar radiation components in Syria using several mathematical models; these models have been tested by a statistical method and then determined the relative percentage error between calculated values and the measured ones; he suggested that the relative error reached the range of $\pm 3 \%$ in the worst case. Evaluation of Oman solar potential was conducted by Al-Hinai and Al-Alawi [6] And Dorvlo and Ampratwum [7]; they have built a database of typical solar radiation for six stations of different locations, for six years. Then, they have estimated for each location the hourly values of the three solar radiation components (global, direct, and diffuse) by the modeling of meteorological data, using polynomial and trigonometric models. They found that the best fit was obtained by the regression based on the ambient temperature and the atmospheric pressure.

An empirical formula for estimating hourly solar radiation over Bahrain has been developed by Al-Sadah et al. [8]; the results obtained were compared with experimental data measured at latitude of $26^{\circ}$ north; a good agreement between two values (estimated and measured) was found.

Evaluation of solar radiation resources in Saudi Arabia has been presented by Al-Abbadi et al. [9]. One and five minute network data are collected and assessed for quality; they were indicating that more than $80 \%$ of the network data fall within quality limits of $\pm 5 \%$. Bahel et al. [10] used an Eppley Pyrheliometer to measure sunshine duration for Dhahran (Saudi Arabia); they have exploited these measurements to derive a linear correlation between the monthly average global solar radiation and sunshine duration, and they noted that there is an agreement between the predicted and measured values better than $4 \%$.

In this paper, the actual solar radiation measurements for the three solar components (global, DNI, and diffuse solar radiation) are presented. In addition, the values of clearness

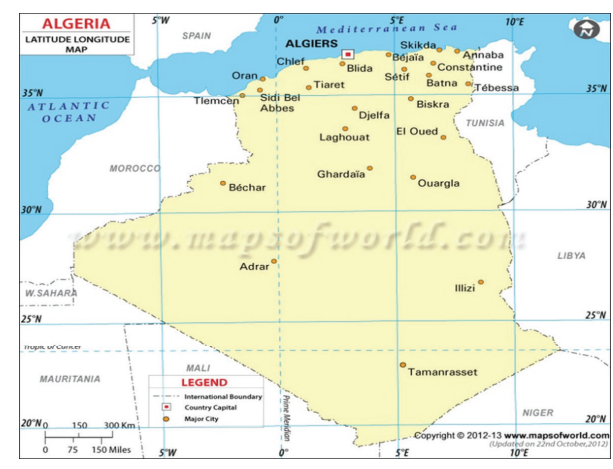

FIGURE 1: Ghardaïa site location [12].

index and sunshine fraction have been discussed. Next, our measurements are compared with the corresponding data available in the literature of some Arab areas and with the data of the NASA SSE model and the Solar-Med-Atlas website. For this purpose, a database for one complete year was used to assess the solar potential in Ghardaïa region.

\section{Description of Study Area}

Ghardaïa site is considered an arid and dry area, located in the south of Algeria, about $600 \mathrm{Km}$ south of the capital city (Figure 1); it is framed by the following geographical coordinates: latitude of $32^{\circ} 36^{\prime} \mathrm{N}$, longitude of $3^{\circ} 48^{\prime} \mathrm{E}$, and altitude of $450 \mathrm{~m}$ above MSL. The site is characterised by an exceptional sunshine where the rate of insolation is significant; the mean annual global solar radiation measured on a horizontal plane exceeds $6000\left(\mathrm{Wh} / \mathrm{m}^{2}\right)$, and the sunshine duration is more than 3000 (hours/year). The winter in Ghardaïa is described by an extreme cold due to windblown of snow from the highlands; sandstorms from the southwest at the end of winter are particularly troublesome, which is the result of extreme dustiness. Temperature is high in summer and can exceed $45^{\circ} \mathrm{C}$ and is relatively cool in winter; the jellies are exceptional and small [11].

\section{Measurements}

The measured data on solar radiation used in the present study were collected by a radiometric station with high precision and installed on the solar radiation laboratory roof of applied research unit for renewable energies (URAER) building (Figures 2 and 3). The station has two parts.

(i) A fixed part consists of two EKO MS-64 pyranometers for the measurement of global radiant flux on a horizontal plane (its short wave sensitivity is 7.0 $\left.\left(\mathrm{mV} / \mathrm{kW} / \mathrm{m}^{2}\right)\right)$ and on inclined surface at the latitude of the site.

(ii) A moving part, which is able to track the path of the sun from sunrise to sunset.

The last one is consisting with an EKO MS-101D pyrheliometer with short wave sensitivity of $6.71\left(\mathrm{mV} / \mathrm{kW} / \mathrm{m}^{2}\right)$, which is pointed at the sun disk for measuring the DNI 


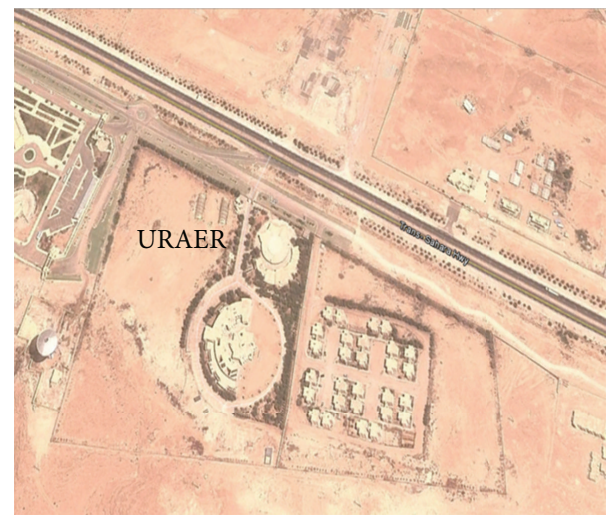

FIGURE 2: Location of measurement station.

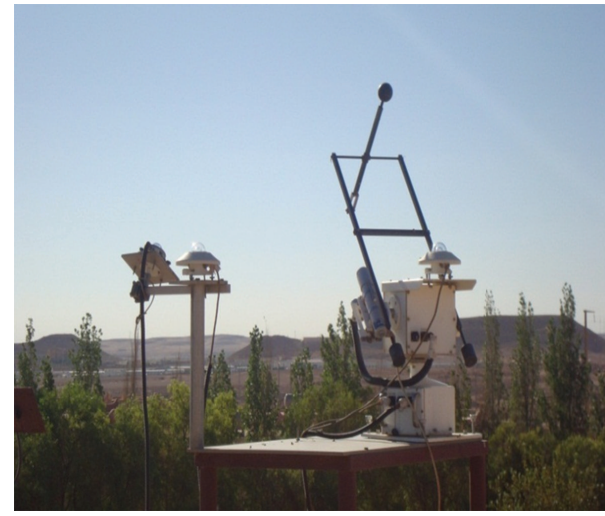

FIgURE 3: Radiometric station.

TABLE 1: Technical specifications of used solar instruments.

\begin{tabular}{lcc}
\hline & $\begin{array}{c}\text { Pyranometer } \\
\text { MS-64 }\end{array}$ & $\begin{array}{c}\text { Pyrheliometer } \\
\text { MS-101D }\end{array}$ \\
\hline Directional response & $< \pm 10 \mathrm{~W} / \mathrm{m}^{2}$ & $< \pm 10 \mathrm{~W} / \mathrm{m}^{2}$ \\
Temperature response & $< \pm 1 \%$ & $< \pm 1 \%$ \\
Non-linearity & $< \pm 0,2 \%$ & $< \pm 0,2 \%$ \\
Tilt response & $< \pm 0,2 \%$ & - \\
Operating temperature & $-40 \sim+80$ & $-20 \sim+60$ \\
range $\left({ }^{\circ} \mathrm{C}\right)$ & $305-2800$ & $200-4000$ \\
Wavelength range $(\mathrm{nm})$ & & \\
\hline
\end{tabular}

TABLE 2: Annual and monthly accumulated solar radiation (kWh/ $\mathrm{m}^{2} /$ day)

\begin{tabular}{lccc}
\hline & Diffuse & DNI & Global \\
\hline Jan. & 29 & 174 & 120 \\
Feb. & 40 & 170 & 140 \\
Mar. & 77 & 153 & 181 \\
Apr. & 70 & 202 & 220 \\
May & 91 & 188 & 240 \\
Jun. & 83 & 192 & 244 \\
Jul. & 77 & 212 & 251 \\
Aug. & 60 & 154 & 163 \\
Sept. & 63 & 156 & 181 \\
Oct. & 51 & 154 & 150 \\
Nov. & 35 & 156 & 121 \\
Dec. & 30 & 156 & 107 \\
\hline Total & 706 & 2067 & 2118 \\
\hline
\end{tabular}

component. Another EKO MS-64 pyranometer with short wave sensitivity of $7.0\left(\mathrm{mV} / \mathrm{kW} / \mathrm{m}^{2}\right)$ for the measurement of diffuse radiant flux on the horizontal plane is equipped with a shadow band for hiding the radiant flux coming directly from the sun. All solar components are made with an interval of five minutes for each one. More technical specifications of used solar instruments are reported in Table 1.

\section{Data Analysis}

4.1. Annual and Monthly Accumulated Solar Radiation. In order to get an overview of solar radiation potential in the area, Table 2 presents the monthly and the annual accumulated values of the three components, which are measured and analysed for a one complete year. It can be seen that the accumulated solar radiation is very important. The annual values were estimated by $2118\left(\mathrm{kWh} / \mathrm{m}^{2} /\right.$ day $)$, $2067\left(\mathrm{kWh} / \mathrm{m}^{2} /\right.$ day $)$, and $706\left(\mathrm{kWh} / \mathrm{m}^{2} /\right.$ day) for global, DNI, and diffuse solar radiations, respectively. Considering the monthly values, the maximum was recorded in July with a value of $251\left(\mathrm{kWh} / \mathrm{m}^{2} /\right.$ day) for global solar radiation and $212\left(\mathrm{kWh} / \mathrm{m}^{2} /\right.$ day $)$ for the DNI solar radiation, while it is $91\left(\mathrm{kWh} / \mathrm{m}^{2} /\right.$ day $)$ for the diffuse solar radiation observed in May.

A comparison of our measurements with satellite data provided by the solar atlas for the Mediterranean (Solar-MedAtlas) website [13] has been made. This website is a portal for global horizontal and DNI solar radiation data for the southern and eastern Mediterranean regions but without the diffuse solar radiation, which covers a period extending to 20 years (1991-2010) of measurements.

The comparisons between the monthly accumulated global and DNI solar radiation have been shown in Figure 4. In general, the measurements are in agreement with the SolarMed-Atlas data for the entire year except for the months of March and August where there are differences between the two values. The relative error between the annual accumulated global solar radiations is $0.6 \%$, where it is about $2 \%$ for the DNI solar radiation. Consequently, our measurements can be considered as representative.

4.2. Daily and Monthly Solar Radiation. The daily maximum and average diffuse, DNI, and global solar radiation components are illustrated in Figure 5 during the entire year. The diffuse values are important in the summer season; the maximum and average irradiance of 1058 and $221\left(\mathrm{~W} / \mathrm{m}^{2}\right)$ was detected in the month of May. For the DNI solar radiation component, the average values are substantial in winter, spring, and autumn and relatively low during the summer 


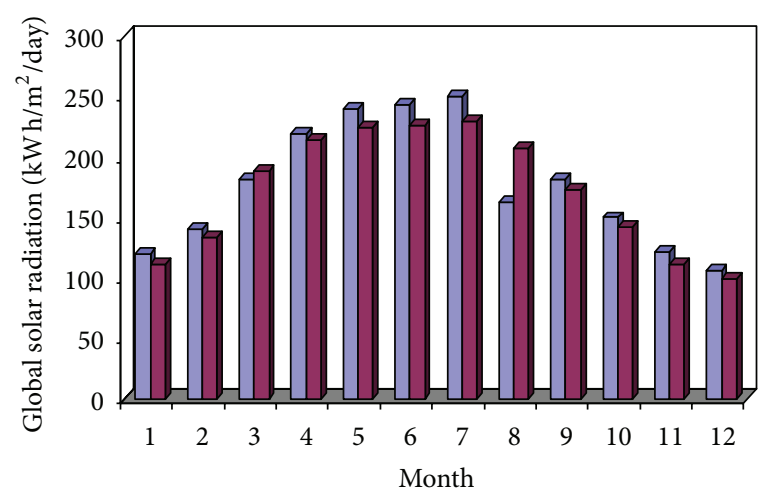

$\square$ URAER data

Solar-med data

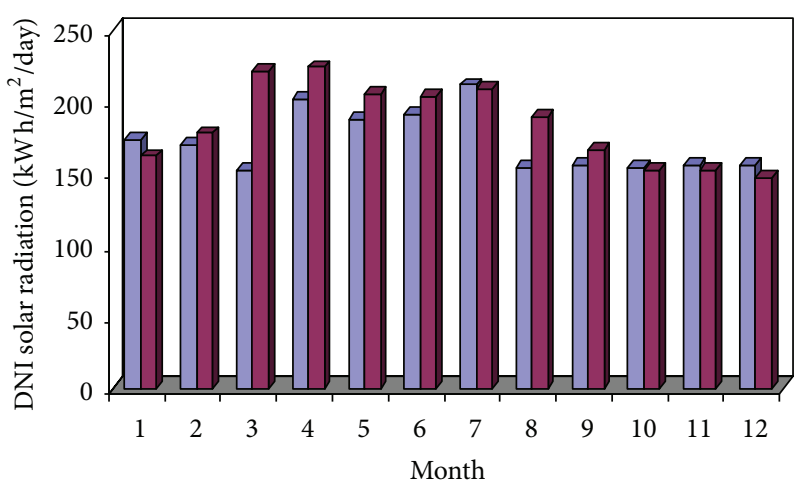

URAER data

Solar-med data

FIGURE 4: Monthly accumulated global and DNI solar radiation.
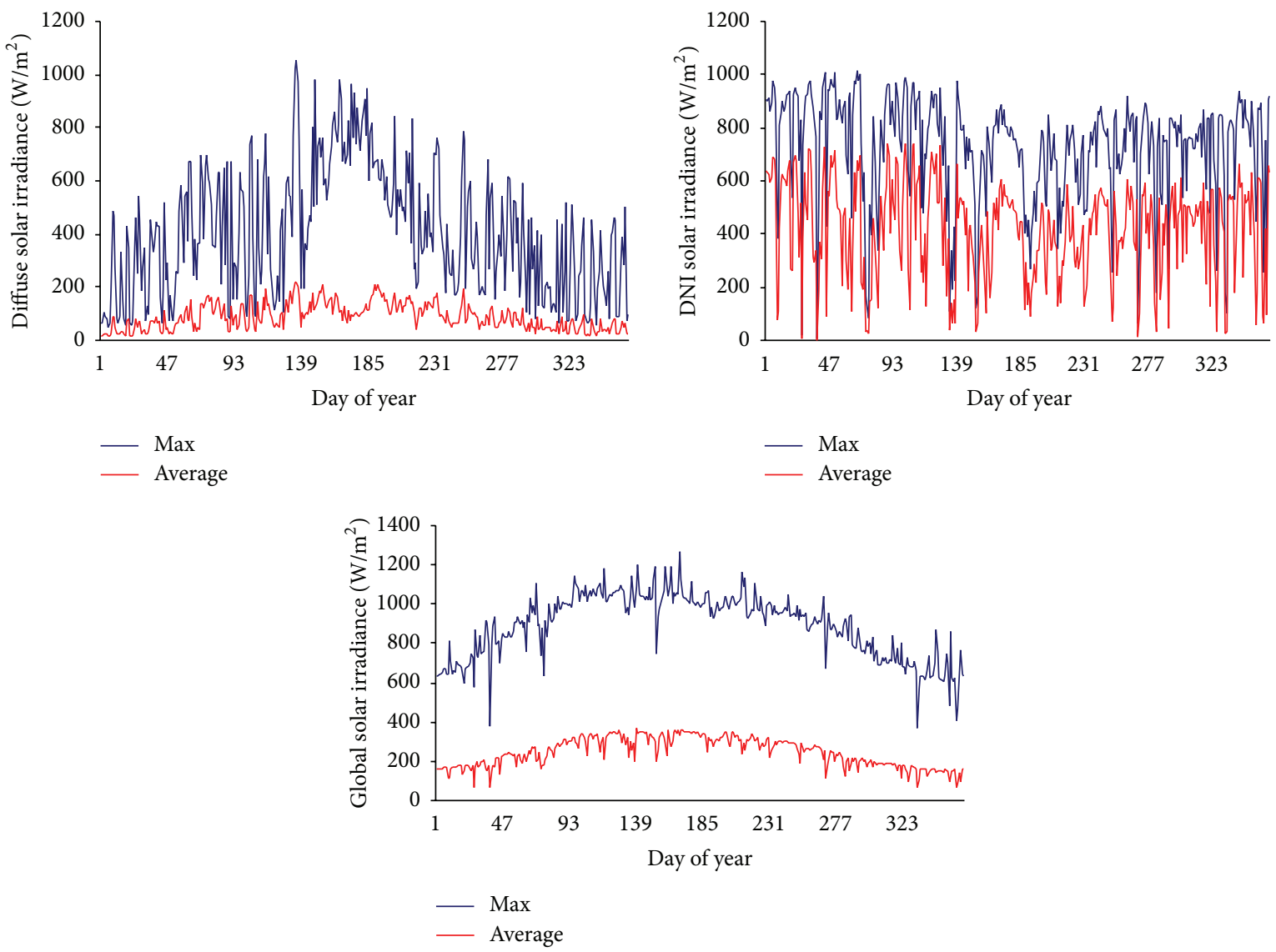

FIGURE 5: Daily average and maximum diffuse, DNI, and global [14] solar radiation.

season; the maximum ones of $1018\left(\mathrm{~W} / \mathrm{m}^{2}\right)$ were recorded in the day number of 68 (09 March), while the highest daily average DNI solar irradiance of $742.73\left(\mathrm{~W} / \mathrm{m}^{2}\right)$ was observed on April 18. Regarding the global solar radiation, data indicates that irradiance is high during the summer months and relatively low during the winter season; the average values are important during the period from March to September, and the highest daily mean and the daily maximum of $1268\left(\mathrm{~W} / \mathrm{m}^{2}\right)$ were recorded in May and June, respectively.

Our experimental data of the monthly mean daily values of solar radiation components are supported with the larger time-series data of the NASA SSE model [15], as presented in Figure 6. Our measurements agreed with the 22-year average 
TABLE 3: Comparison between the monthly mean daily diffuse solar radiation ( $\mathrm{kWh} / \mathrm{m}^{2} /$ day) for Ghardaïa and other sites from the MENA region.

\begin{tabular}{|c|c|c|c|c|c|c|c|c|c|c|c|c|c|}
\hline Site & Jan. & Feb. & Mar. & Apr. & May. & Jun. & Jul. & Aug. & Sep. & Oct. & Nov. & Dec. & Annual \\
\hline Ghardaïa & 0.9 & 1.4 & 1.8 & 1.9 & 2.0 & 2.1 & 1.9 & 1.8 & 1.8 & 1.7 & 1.1 & 1.0 & 1.6 \\
\hline Algiers & 0.9 & 1.3 & 1.7 & 2.0 & 2.3 & 2.4 & 2.2 & 2.0 & 1.8 & 1.4 & 1.1 & 0.8 & 1.7 \\
\hline Oran & 1.0 & 1.3 & 1.7 & 2.1 & 2.2 & 2.3 & 2.3 & 2.1 & 1.7 & 1.5 & 1.0 & 0.9 & 1.7 \\
\hline Tamanrasset & 1.1 & 1.3 & 1.8 & 2.0 & 2.4 & 2.6 & 2.4 & 2.3 & 2.2 & 1.5 & 1.2 & 1.1 & 1.8 \\
\hline Tunis & 1.2 & 1.4 & 1.8 & 2.2 & 2.6 & 2.3 & 2.1 & 1.9 & 1.7 & 1.6 & 1.2 & 1.0 & 1.7 \\
\hline Marrakech & 1.2 & 1.5 & 1.8 & 2.1 & 2.2 & 2.1 & 1.8 & 1.8 & 1.8 & 1.6 & 1.3 & 1.2 & 1.7 \\
\hline Tripoli & 1.1 & 1.2 & 1.7 & 2.1 & 2.3 & 2.3 & 2.2 & 2.1 & 1.8 & 1.5 & 1.2 & 1.0 & 1.7 \\
\hline Cairo & 1.3 & 1.6 & 1.9 & 2.4 & 2.4 & 2.2 & 2.1 & 2.1 & 1.8 & 1.5 & 1.3 & 1.2 & 1.8 \\
\hline Abu Dhabi & 1.3 & 1.8 & 2.0 & 2.0 & 2.1 & 2.2 & 2.5 & 2.3 & 1.5 & 1.3 & 1.1 & 1.2 & 1.8 \\
\hline Kuwait & 1.1 & 1.2 & 1.9 & 2.1 & 2.7 & 1.7 & 2.2 & 1.5 & 1.2 & 1.2 & 1.2 & 1.0 & 1.6 \\
\hline Baghdad & 1.2 & 1.3 & 1.9 & 2.2 & 2.4 & 2.4 & 2.3 & 2.1 & 1.9 & 1.6 & 1.3 & 1.1 & 1.7 \\
\hline Muscat & 1.5 & 1.6 & 2.1 & 2.2 & 2.3 & 2.4 & 2.4 & 2.3 & 2.1 & 1.8 & 1.6 & 1.5 & 2.0 \\
\hline
\end{tabular}
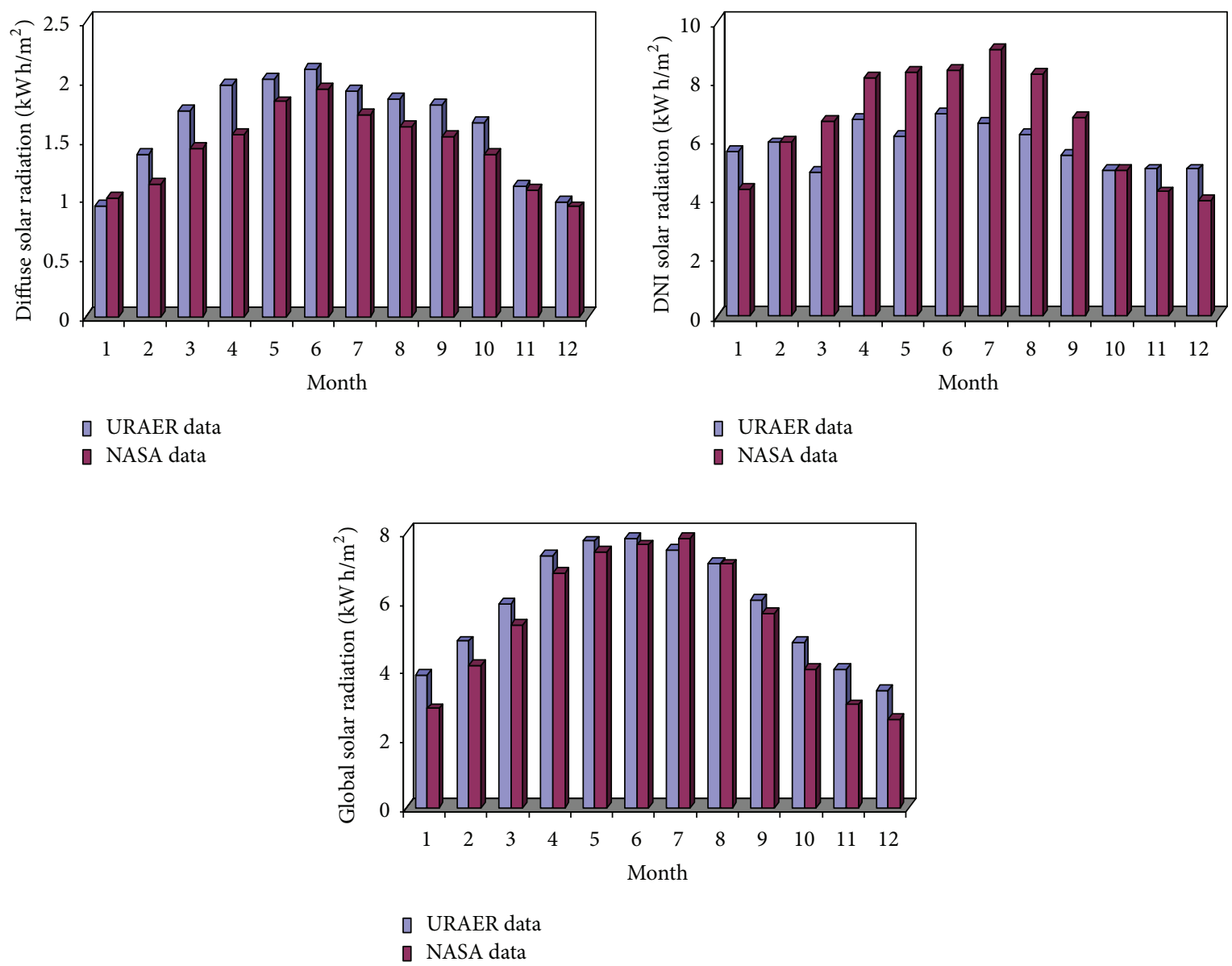

FIGURE 6: Monthly diffuse, DNI, and global solar radiation.

solar radiation data of the NASA SSE model with some discrepancy especially in summer season, mainly for the DNI solar radiation.

The monthly mean daily values of diffuse solar radiation, DNI solar radiation, and the global solar radiation of the Ghardaïa area have been supported also to some other sites from the MENA region reported by Alnaser et al. [2], as arranged in Tables 3, 4, and 5. It is clear that the monthly average of global and DNI solar radiation over the course of the year is comparatively higher for Ghardaïa. The monthly mean diffuse solar radiation is considered lower, compared with other Arab locations. 
TABLE 4: Comparison between the monthly mean daily DNI solar radiation ( $\mathrm{kWh} / \mathrm{m}^{2} /$ day) for Ghardaïa and other sites from the MENA region.

\begin{tabular}{lccccccccccccc}
\hline Site & Jan. & Feb. & Mar. & Apr. & May. & Jun. & Jul. & Aug. & Sep. & Oct. & Nov. & Dec. & Annual \\
\hline Ghardaïa & $\mathbf{5 . 6}$ & $\mathbf{5 . 9}$ & $\mathbf{4 . 9}$ & $\mathbf{6 . 7}$ & $\mathbf{6 . 1}$ & $\mathbf{7 . 2}$ & $\mathbf{8 . 3}$ & $\mathbf{5 . 6}$ & $\mathbf{5 . 2}$ & $\mathbf{5 . 0}$ & $\mathbf{5 . 0}$ & $\mathbf{5 . 0}$ & $\mathbf{5 . 5}$ \\
Oran & 3.4 & 3.8 & 3.9 & 5.2 & 5.4 & 5.4 & 5.4 & 5.2 & 4.9 & 3.2 & 3.1 & 3.0 & 4.3 \\
Tunis & 2.4 & 3.2 & 3.6 & 4.4 & 5.1 & 6.3 & 6.7 & 6.2 & 5.1 & 3.6 & 2.8 & 2.4 & 4.3 \\
Cairo & 3.3 & 3.5 & 4.4 & 5.1 & 5.5 & 6.6 & 6.3 & 6.0 & 5.4 & 4.4 & 3.6 & 3.1 & 4.8 \\
Kuwait & 3.7 & 4.5 & 5.4 & 6.3 & 6.1 & 8.3 & 7.1 & 7.7 & 6.9 & 5.3 & 5.7 & 3.8 & 5.9 \\
Bahrain & 2.4 & 3.3 & 3.0 & 4.0 & 4.8 & 5.4 & 5.0 & 4.6 & 4.3 & 3.6 & 2.8 & 2.1 & 3.8 \\
\hline
\end{tabular}
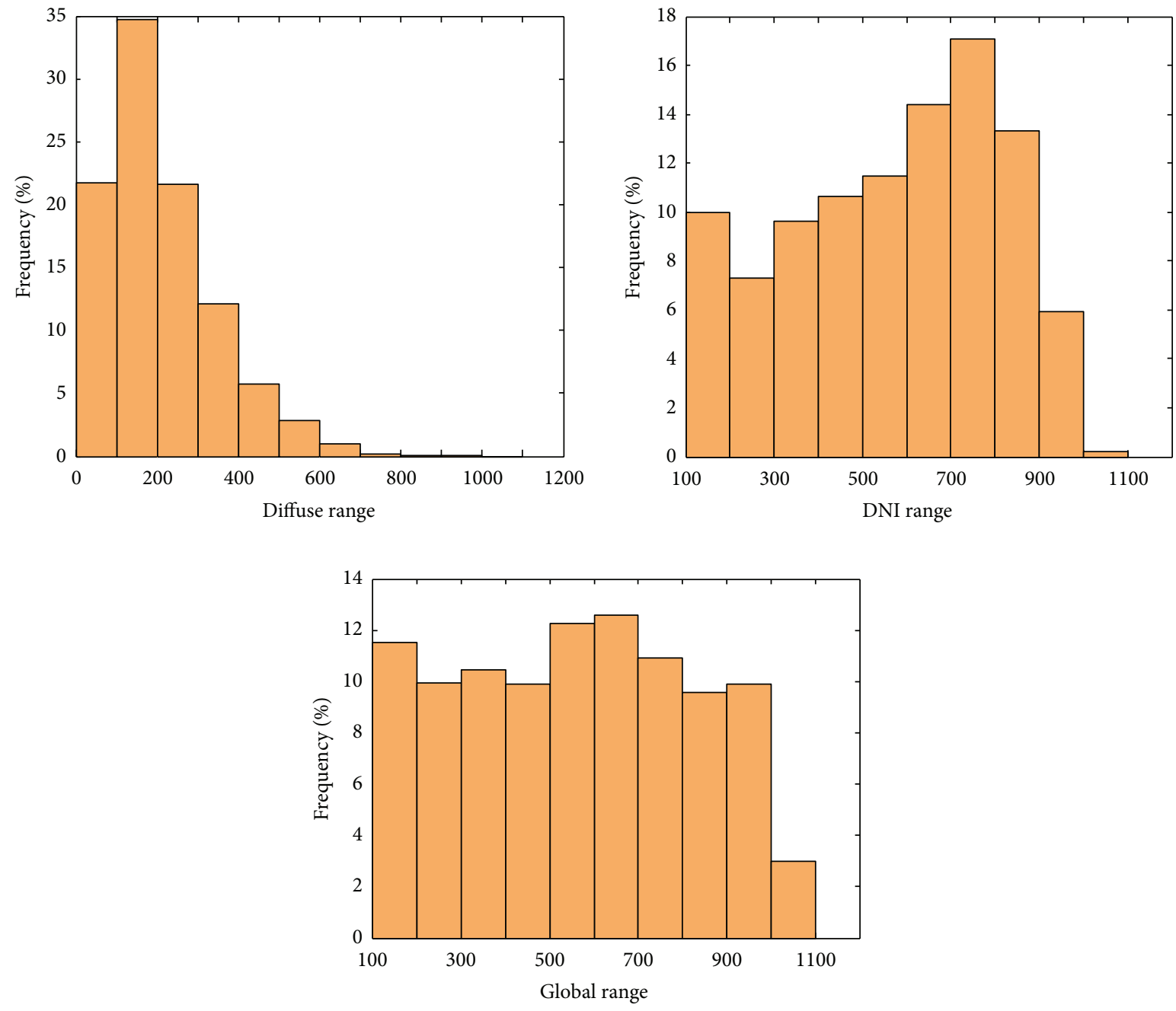

FIGURE 7: Frequency distribution of diffuse, DNI, and global solar radiation.

4.3. Frequency Distribution of Solar Radiation. The frequency distribution of the three solar radiation components is shown in Figure 7. For the diffuse solar radiation, it can be reported that $23 \%$ of frequencies are between $0-100\left(\mathrm{Wh} / \mathrm{m}^{2}\right), 35 \%$ receive between $100-200\left(\mathrm{Wh} / \mathrm{m}^{2}\right), 23 \%$ get between $200-300$ $\left(\mathrm{Wh} / \mathrm{m}^{2}\right)$, while $12 \%$ of frequencies obtain between $300-400$ $\left(\mathrm{Wh} / \mathrm{m}^{2}\right), 6 \%$ get between $500-600\left(\mathrm{Wh} / \mathrm{m}^{2}\right)$, and less than $5 \%$ of the frequencies for the rest. For the DNI component, $14.3 \%$ of the data are between $600-700\left(\mathrm{Wh} / \mathrm{m}^{2}\right), 17 \%$ of frequencies obtain between $700-800\left(\mathrm{Wh} / \mathrm{m}^{2}\right)$, and $13 \%$ are between $800-900\left(\mathrm{Wh} / \mathrm{m}^{2}\right)$. We can note that this analysis is advantageous mostly for users who tend to do the CSP technology.

Regarding the global solar radiation received on a horizontal plane, it is found that more than $12 \%$ of the frequencies are between $500-600\left(\mathrm{Wh} / \mathrm{m}^{2}\right)$ and between $600-$ $700\left(\mathrm{Wh} / \mathrm{m}^{2}\right), 10.5 \%$ receive between $700-800\left(\mathrm{Wh} / \mathrm{m}^{2}\right)$, 9.98\% get between $900-1000\left(\mathrm{Wh} / \mathrm{m}^{2}\right)$, and only $3 \%$ between 
TABLE 5: Comparison between the monthly mean daily global solar radiation ( $\mathrm{kWh} / \mathrm{m}^{2} /$ day) for Ghardaïa and other sites from the MENA region.

\begin{tabular}{lccccccccccccc}
\hline Site & Jan. & Feb. & Mar. & Apr. & May. & Jun. & Jul. & Aug. & Sep. & Oct. & Nov. & Dec. & Annual \\
\hline Ghardaïa & $\mathbf{3 . 9}$ & $\mathbf{4 . 8}$ & $\mathbf{5 . 9}$ & $\mathbf{7 . 3}$ & $\mathbf{7 . 7}$ & $\mathbf{7 . 8}$ & $\mathbf{7 . 5}$ & $\mathbf{7 . 1}$ & $\mathbf{6 . 0}$ & $\mathbf{4 . 8}$ & $\mathbf{4 . 0}$ & $\mathbf{3 . 4}$ & $\mathbf{5 . 8}$ \\
Algiers & 2.2 & 3.0 & 4.1 & 4.9 & 6.0 & 6.2 & 7.0 & 6.4 & 5.1 & 3.3 & 2.7 & 2.2 & 4.4 \\
Oran & 2.8 & 3.7 & 4.9 & 6.2 & 6.9 & 7.4 & 7.5 & 6.8 & 5.6 & 4 & 2.9 & 2.4 & 5.1 \\
Tamanrasset & 5.2 & 6.1 & 6.9 & 7.7 & 7.8 & 7.7 & 7.6 & 7.4 & 6.7 & 6.0 & 5.2 & 4.8 & 6.6 \\
Tunis & 2.4 & 3.1 & 4.4 & 5.7 & 6.5 & 7.3 & 7.4 & 6.6 & 5.3 & 4.0 & 2.9 & 2.3 & 4.8 \\
Marrakech & 3.4 & 4.2 & 5.2 & 6.0 & 6.7 & 7.3 & 7.6 & 7.0 & 5.9 & 4.6 & 3.6 & 3.2 & 5.4 \\
Tripoli & 2.9 & 4.0 & 5.0 & 6.0 & 6.5 & 7.0 & 7.1 & 6.5 & 5.5 & 4.0 & 3.1 & 2.3 & 5.0 \\
Cairo & 5.7 & 4.0 & 5.2 & 6.3 & 7.1 & 7.6 & 7.4 & 6.8 & 5.9 & 4.7 & 3.5 & 5.9 & 5.4 \\
Abu Dhabi & 4.3 & 5.0 & 5.7 & 6.7 & 7.6 & 7.6 & 7.0 & 6.7 & 6.5 & 5.7 & 4.8 & 4.0 & 6.0 \\
Kuwait & 3.1 & 4.1 & 5.5 & 6.2 & 7.1 & 7.9 & 7.5 & 7.1 & 6.2 & 4.8 & 3.4 & 2.9 & 5.5 \\
Baghdad & 3.0 & 3.8 & 4.8 & 5.7 & 6.5 & 7.3 & 7.2 & 6.6 & 5.7 & 4.4 & 3.3 & 2.7 & 5.1 \\
Muscat & 4.0 & 4.7 & 5.5 & 6.3 & 6.9 & 6.7 & 6.1 & 6.0 & 5.8 & 5.2 & 4.4 & 3.8 & 5.4 \\
\hline
\end{tabular}

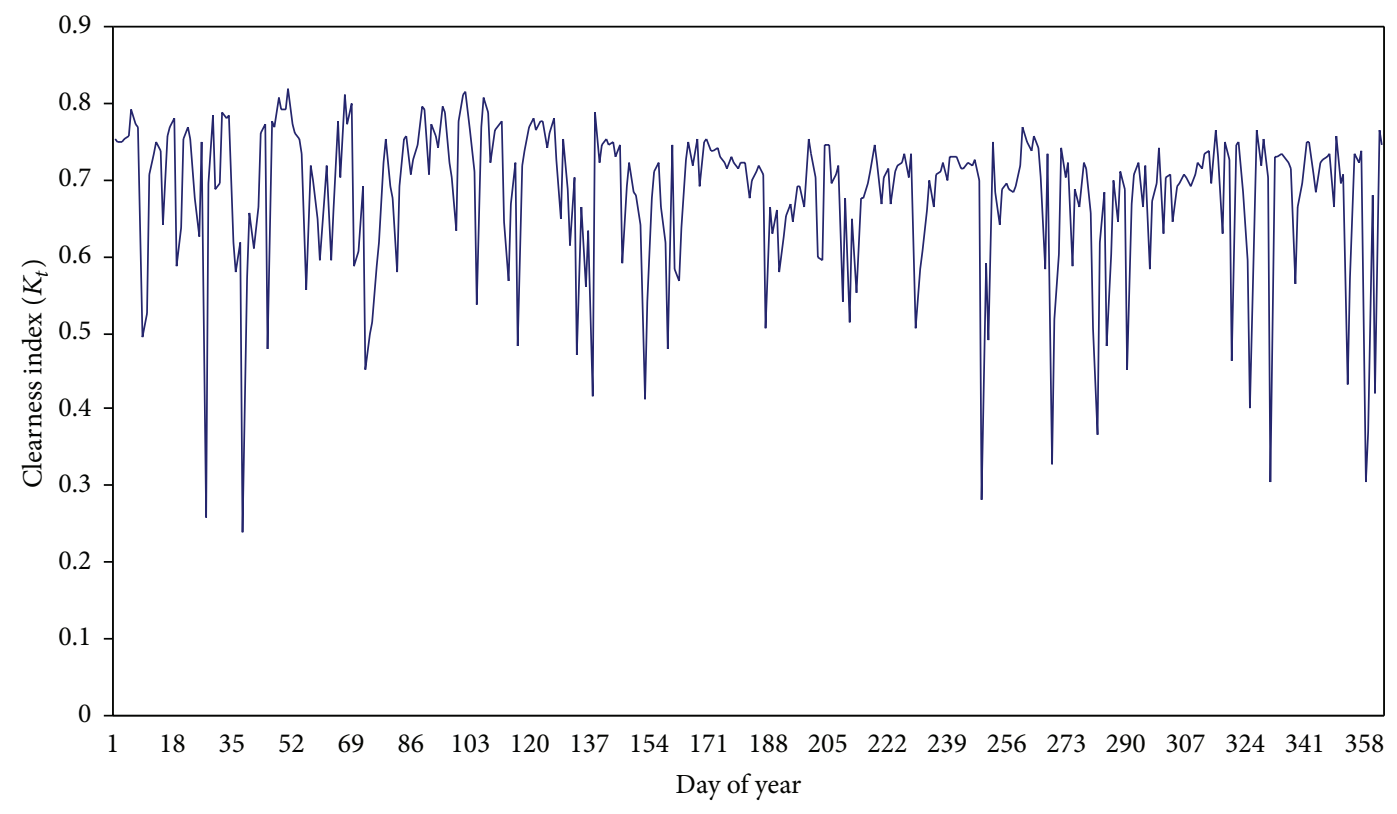

FIGURE 8: Daily variation of clearness index $\left(K_{t}\right)$.

1000-1100 $\left(\mathrm{Wh} / \mathrm{m}^{2}\right)$. This can be important for some solar applications that use global solar radiation as an input parameter for sizing.

4.4. Frequency Distribution of Clearness Index and Sunshine Fraction. The clearness index $K_{t}$ is the ratio of global monthly average solar radiation measured on a horizontal surface $(H)$ to the monthly average extraterrestrial radiation $\left(H_{0}\right)$ and can be determined from the following [16, 17]:

$$
\begin{gathered}
K_{t}=\frac{H}{H_{0}}, \\
H_{0}=\frac{24}{\pi} G_{\mathrm{SC}}\left(1+0.033 \frac{360 n}{365}\right) \\
\times\left(\cos \phi \cos \delta \sin \omega+\frac{2 \pi}{360} \omega \sin \phi \sin \delta\right),
\end{gathered}
$$

$$
\begin{gathered}
\delta=23.45 \sin \left(360 \frac{284+n}{365}\right), \\
\omega=\cos ^{-1}(-\tan \phi \tan \delta),
\end{gathered}
$$

where $\phi$ is the latitude of the site and $G_{S C}$ is the solar constant equal to $1367\left(\mathrm{~W} / \mathrm{m}^{2}\right)$.

The daily variation of the clearness index for a whole year is presented in Figure 8. The clearness index variations range between 0.5 and 0.8 , except for a few days where we observed some downward excursions when the sky conditions dramatically reduce the solar radiation energy. The monthly average clearness index is a constant value of approximately 0.67 . The 22 -year monthly average clearness indexes for selected Arab sites are compared with that of 

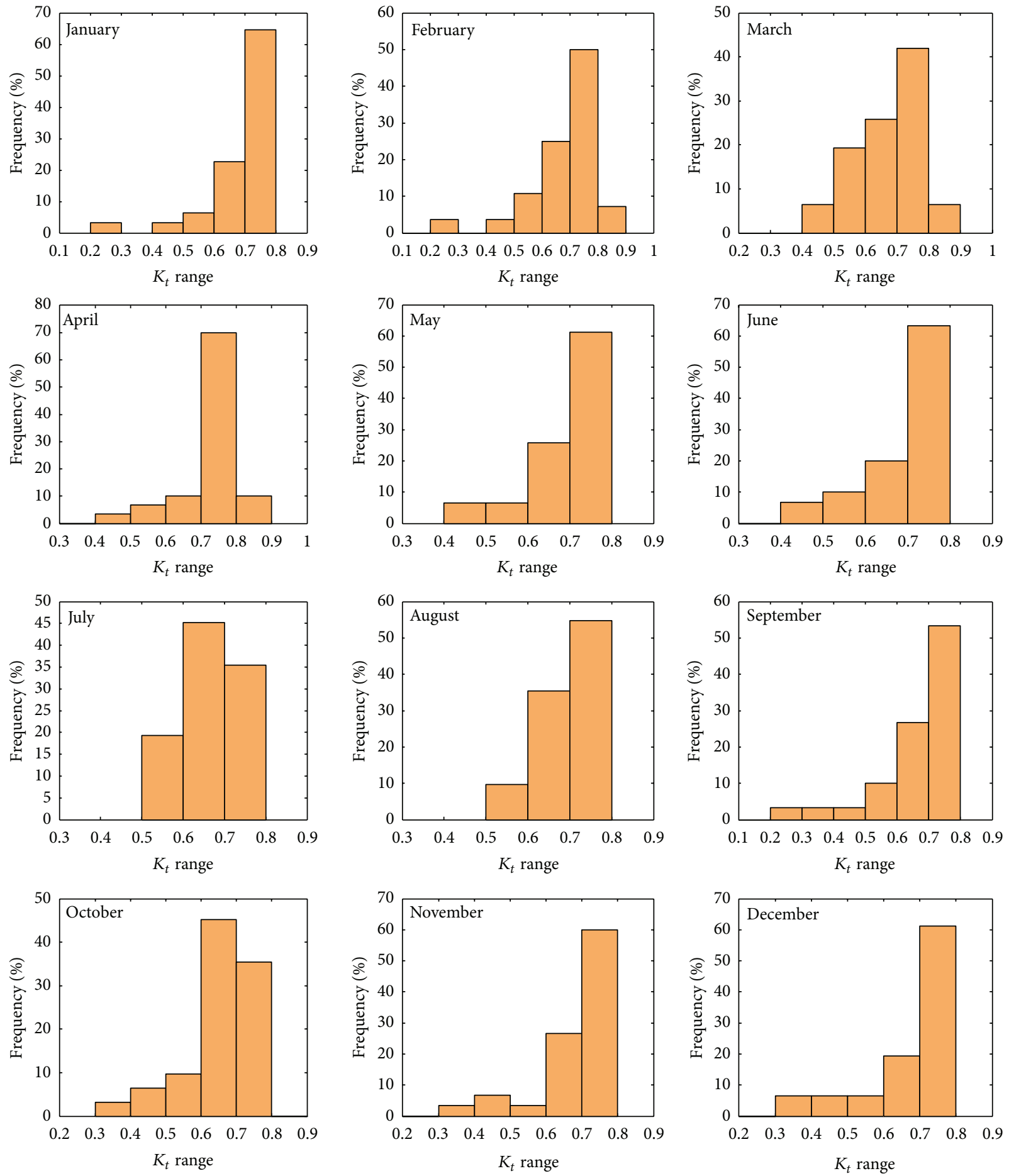

FIGURE 9: Frequency distribution of clearness index for each month.

Ghardaïa using the NASA SSE model as tabulated in Table 6. There are no significant differences between the NASA data and our measurements. This analysis is confirmed by the frequency distribution graphs shown in Figure 9, where more than $50 \%$ of the frequencies have values between $0.7-0.8$ for all months, except July and October when $K_{t}$ turns around 0.6-0.7.
The sunshine fraction is the ration between effective sunshine duration $(n)$ and maximum daylight $(N)$; it can be described by $[16,17]$

$$
\begin{gathered}
\sigma=\frac{n}{N}, \\
N=\frac{2}{15} \cos ^{-1}(-\tan \phi \tan \delta) .
\end{gathered}
$$


TABLE 6: Monthly averaged clearness index of Ghardaïa and some Arab sites.

\begin{tabular}{lcccccccccccccc}
\hline & Jan. & Feb. & Mar. & Apr. & May. & Jun. & Jul. & Aug. & Sep. & Oct. & Nov. & Dec. & Annual \\
\hline Ghardaïa & $\mathbf{0 . 6 9}$ & $\mathbf{0 . 6 9}$ & $\mathbf{0 . 6 7}$ & $\mathbf{0 . 7 2}$ & $\mathbf{0 . 6 9}$ & $\mathbf{0 . 6 8}$ & $\mathbf{0 . 6 6}$ & $\mathbf{0 . 6 8}$ & $\mathbf{0 . 6 6}$ & $\mathbf{0 . 6 4}$ & $\mathbf{0 . 6 7}$ & $\mathbf{0 . 6 6}$ & $\mathbf{0 . 6 7}$ \\
NASA Data & 0.55 & 0.62 & 0.58 & 0.69 & 0.67 & 0.64 & 0.70 & 0.65 & 0.66 & 0.50 & 0.46 & 0.47 & 0.60 \\
Algiers & 0.42 & 0.45 & 0.50 & 0.51 & 0.55 & 0.61 & 0.63 & 0.61 & 0.60 & 0.55 & 0.49 & 0.41 & 0.53 \\
Tunis & 0.47 & 0.50 & 0.51 & 0.52 & 0.57 & 0.59 & 0.64 & 0.61 & 0.53 & 0.48 & 0.47 & 0.47 & 0.53 \\
Abu Dhabi & 0.55 & 0.59 & 0.59 & 0.59 & 0.60 & 0.59 & 0.59 & 0.60 & 0.61 & 0.62 & 0.57 & 0.46 & 0.58 \\
Kuwait & 0.52 & 0.57 & 0.56 & 0.56 & 0.62 & 0.69 & 0.68 & 0.67 & 0.65 & 0.60 & 0.5 & 0.47 & 0.59 \\
Baghdad & 0.55 & 0.59 & 0.58 & 0.53 & 0.58 & 0.65 & 0.62 & 0.64 & 0.61 & 0.54 & 0.52 & 0.52 & 0.58 \\
Riyadh & 0.54 & 0.57 & 0.57 & 0.59 & 0.64 & 0.70 & 0.68 & 0.67 & 0.65 & 0.65 & 0.59 & 0.54 & 0.62 \\
\hline
\end{tabular}

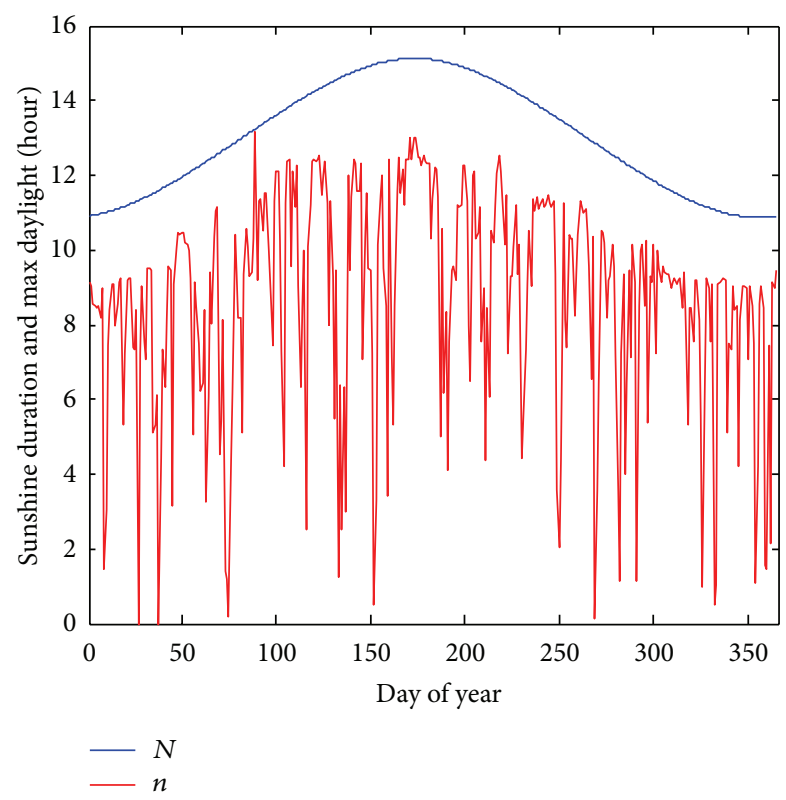

FIGURE 10: Sunshine duration and maximum daylight.

The evolution of the effective sunshine duration, maximum daylight, and sunshine fraction distribution are shown in Figures 10 and 11. The amount of daylight hours can be considerable; the summer season shows the peak of daylight hours with the maximum value occurring in June, while the winter season exposes lower daylight hour in December. The analysis of the sunshine fraction frequency distribution specified that $35 \%$ of frequencies receive values between 0.8 0.9 , reflecting the abundance of sunshine in the area.

4.5. Hourly Distribution of Solar Radiation. The knowledge of the hourly distribution of solar radiation is the basis of sizing and design of many solar applications; however, the performance of some solar systems is sensitive to various design variables. Therefore, it is essential to know that sites with global solar radiation of $500\left(\mathrm{~W} / \mathrm{m}^{2}\right)$ and with DNI of $700\left(\mathrm{~W} / \mathrm{m}^{2}\right)$ are considered an economical area for PV and CSP applications. Figure 12 shows the hourly distribution of the three solar radiation components; the utility of these graphs is to identify the amount of energy available every hour of the day and for each month of the year. The contours of hourly distribution are processed by the following steps.

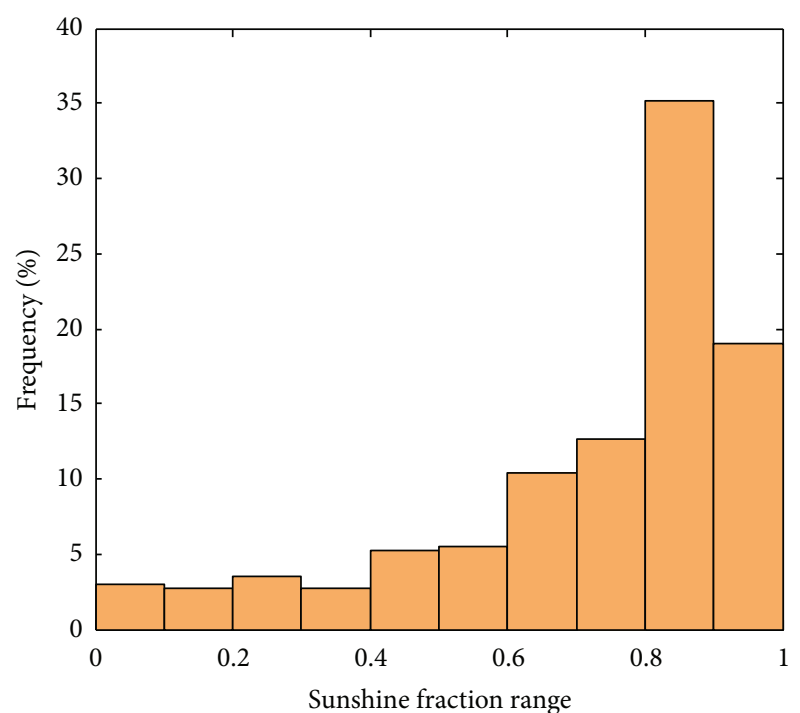

FIGURE 11: Frequency distribution of sunshine fraction.

For each corresponding hour of the day and for each month, the hourly solar radiation is determined and averaged. Then, a matrix containing three kinds of information (month/hour/solar energy) is obtained; therefore, the contours of hourly solar radiation distribution are plotted.

An integrated view of these figures illustrates that there is an evident variation in the solar radiation the autumn season recorded the highest values of solar radiation for the diffuse component for example, while the months from February to May registered the significant amount of DNI solar radiation, but the greatest values were recorded in March. For the global solar radiation, the peak is observed in June with a value of $1080\left(\mathrm{~W} / \mathrm{m}^{2}\right)$ around midday.

For this objective, users are advised to set their systems optimally to improve efficiency and get better gain of solar systems.

\section{Conclusion}

The present analysis has the aim to help engineers and designers in evaluating the Ghardaïa area potential for solar energy applications. 


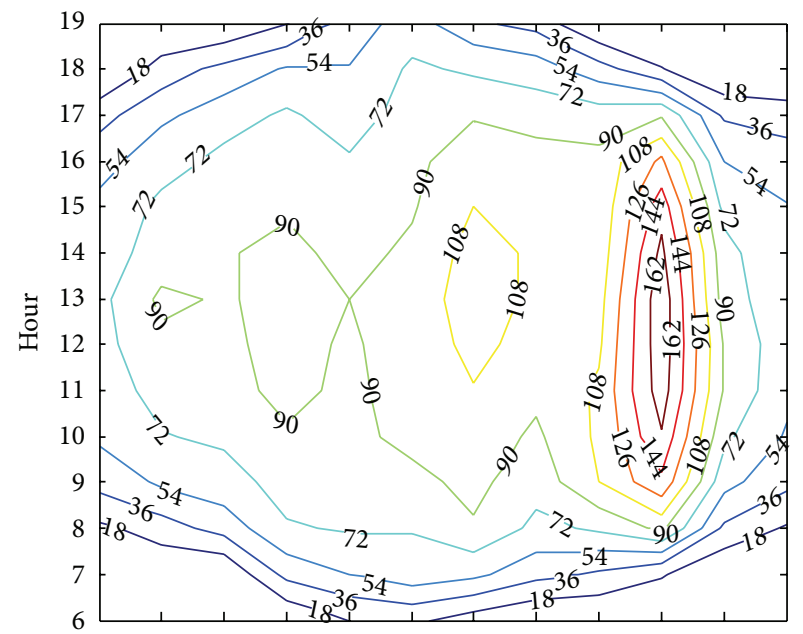

Jan. Feb. Mar. Apr. May Jun. Jul. Aug. Sep. Oct. Nov. Dec. Month

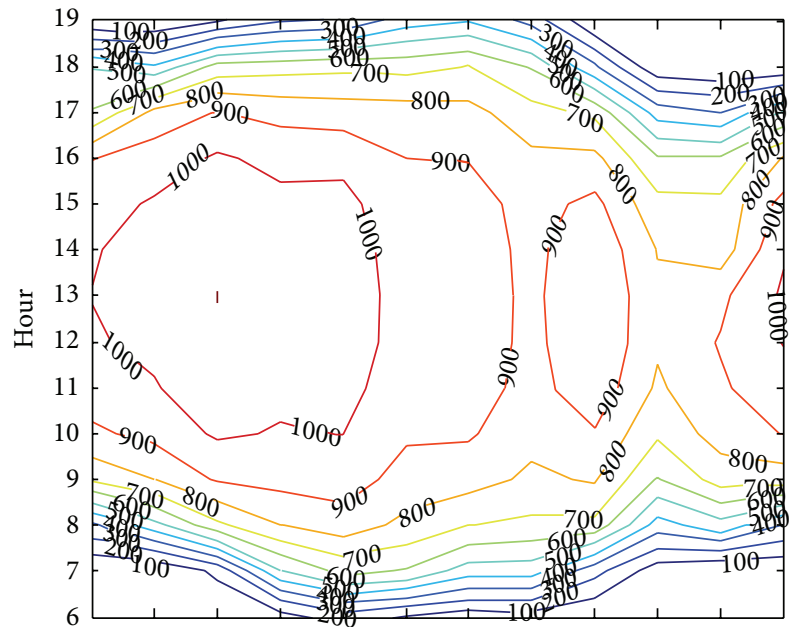

Jan. Feb. Mar. Apr. May. Jun. Jul. Aug. Sep. Oct. Nov. Dec.

Month

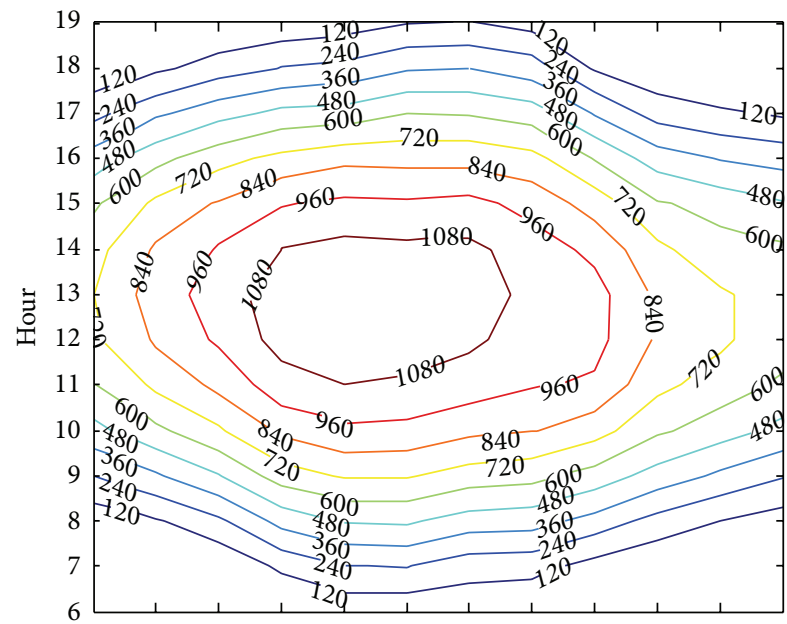

Jan. Feb. Mar. Apr. May. Jun. Jul. Aug. Sep. Oct. Nov. Dec.

Month

FIGURE 12: Hourly distribution of global solar radiation.

The annual accumulated solar radiation is important where it is about $2118\left(\mathrm{kWh} / \mathrm{m}^{2}\right)$ for the global solar radiation and $2067\left(\mathrm{kWh} / \mathrm{m}^{2}\right)$ for DNI solar radiation. The daily solar radiation is also considerable; its evolutions show a maximum of $1018\left(\mathrm{~W} / \mathrm{m}^{2}\right)$ for DNI solar radiation and $1268\left(\mathrm{~W} / \mathrm{m}^{2}\right)$ for the global solar radiation. The NASA SSE model and the Solar-Med-Atlas support our measurements as representative ones; the analysis of the frequency distribution of clearness index indicated that the range of $0.7-0.8$ is the most dominate, which also matched the NASA model and reflected the clear sky conditions in most time of the year. The hourly distribution has a particular interest to identify an economical area for solar applications, where it was seen that Ghardaïa site has this characteristic.

The results presented in the paper indicate that the solar energy in Ghardaiia is a promising solution to conventional energy and could be the starting point of a solar industry in the region.

\section{References}

[1] Algerian Ministry of Energy and Mining, Renewable Energy Program and Energy Efficiency, Algerian Ministry of Energy and Mining, Alger Gare, Algeria, 2011.

[2] W. E. Alnaser, B. Eliagoubi, A. Al-Kalak et al., "First solar radiation atlas for the Arab world," Journal of Renewable Energy, vol. 29, no. 7, pp. 1085-1107, 2004.

[3] A. A. Trabea, "Analysis of solar radiation measurements at AlArish area, North Sinai, Egypt," Journal of Renewable Energy, vol. 20, no. 1, pp. 109-125, 2000.

[4] M. M. Shaltout, A. H. Hassan, and A. M. Fathy, "Study of the solar radiation over Menia," Journal of Renewable Energy, vol. 23, no. 3-4, pp. 621-639, 2001.

[5] A. Al-Mohamad, "Global, direct and diffuse solar-radiation in Syria," Journal of Applied Energy, vol. 79, no. 2, pp. 191-200, 2004.

[6] H. A. Al-Hinai and S. M. Al-Alawi, “Typical solar radiation data for Oman," Journal of Applied Energy, vol. 52, no. 2-3, pp. 153163, 1995. 
[7] A. S. S. Dorvlo and D. B. Ampratwum, "Modelling of weather data for Oman," Journal of Renewable Energy, vol. 17, no. 3, pp. 421-428, 1999.

[8] F. H. Al-Sadah, F. M. Ragab, and M. K. Arshad, "Hourly solar radiation over Bahrain," Journal of Energy, vol. 15, no. 5, pp. 395402, 1990.

[9] N. M. Al-abbadi, S. H. Alawaji, M. Y. bin Mahfoodh, D. R. Myers, S. Wilcox, and M. Anderberg, "Saudi Arabian solar radiation network operation data collection and quality assessment," Journal of Renewable Energy, vol. 25, no. 2, pp. 219-234, 2002.

[10] V. Bahel, R. Srinivasan, and H. Bakhsh, "Solar radiation for Dhahran, Saudi Arabia," Journal of Energy, vol. 11, no. 10, pp. 985-989, 1986.

[11] K. Gairaa, Characterization and evaluation of solar radiation in Ghardaïa site [M.S. thesis], University of Annaba, Annaba, Algeria, 2012.

[12] http://www.mapsofworld.com/.

[13] http://www.solar-med-atlas.org/.

[14] K. Gairaa and Y. Bakelli, "An overview of global solar radiation measurements in Ghardaïa area, south Algeria," International Journal of Energy and Environment, vol. 2, pp. 255-260, 2011.

[15] http://eosweb.larc.nasa.gov/sse.

[16] M. Iqbal, An Introduction to Solar Radiation, Academic Press, Ontario, Canada, 1983.

[17] J. A. Duffie and W. A. Beckman, Solar Engineering of Thermal Process, Wiley, New York, NY, USA, 3rd edition, 2006. 


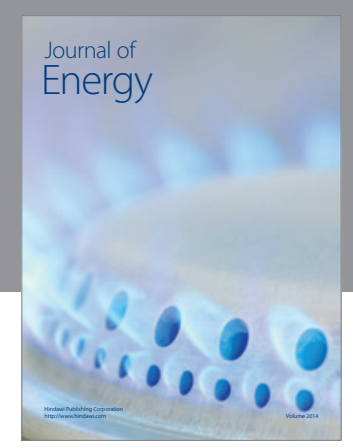

Journal of

Industrial Engineering
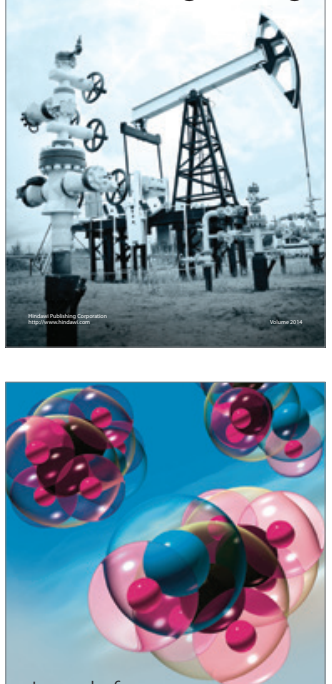

Fuels
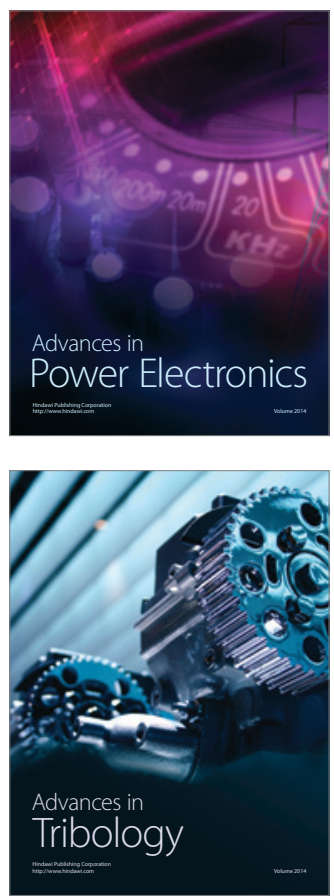

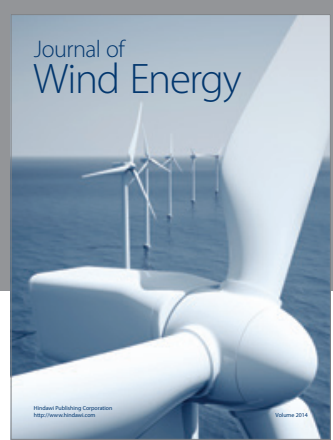

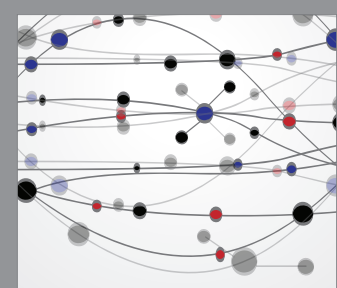

The Scientific World Journal

Submit your manuscripts at http://www.hindawi.com

Journal of

Structures
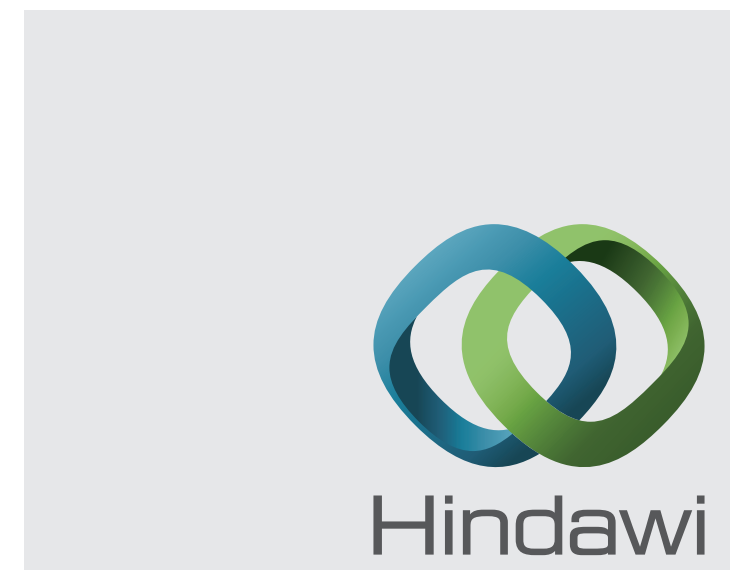

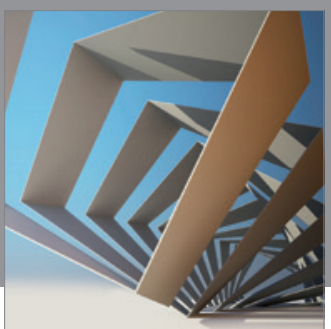

Rotating

Machinery
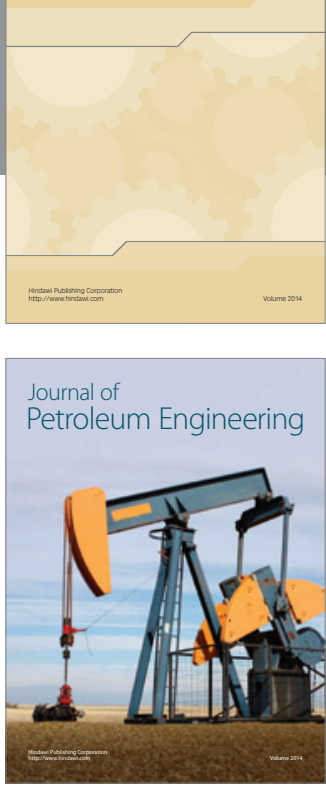

Journal of

Solar Energy
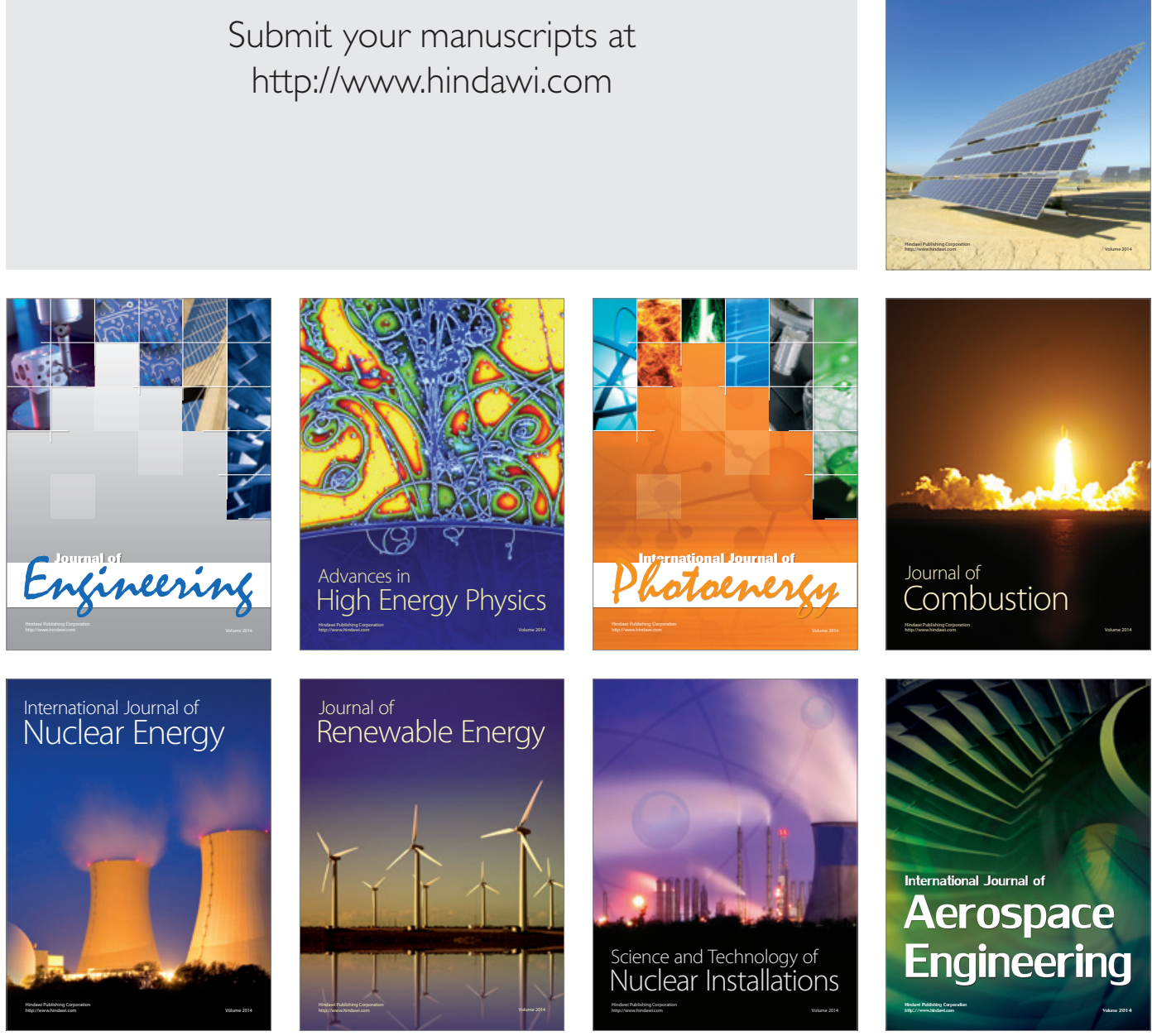